\title{
HLA-DRB3 Gene
}

National Cancer Institute

\section{Source}

National Cancer Institute. HLA-DRB3 Gene. NCI Thesaurus. Code C71259.

This gene is involved in immunoregulation and antigen presentation. 